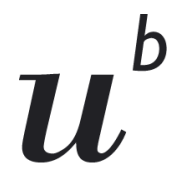

b UNIVERSITÄT BERN

Faculty of Business, Economics and Social Sciences

Department of Economics

\title{
Reserves For All?
}

Central Bank Digital Currency, Deposits, and their (Non)-Equivalence

Dirk Niepelt

$18-13$

July 2018

\section{DISCUSSION PAPERS}




\title{
Reserves For All? \\ Central Bank Digital Currency, Deposits, and their (Non)-Equivalence*
}

\author{
Dirk Niepelt ${ }^{\dagger}$
}

July 21, 2018

\begin{abstract}
I offer a macroeconomic perspective on the "Reserves for All" (RFA) proposal to let the general public use electronic central bank money. After distinguishing RFA from cryptocurrencies and relating the proposal to discussions about narrow banking and the abolition of cash I propose an equivalence result according to which a marginal substitution of outside for inside money does not affect macroeconomic outcomes. I identify key conditions on bank and government (central bank) incentives for equivalence and argue that these conditions likely are violated, implying that RFA would change macroeconomic outcomes. I also relate my analysis to common arguments in the discussion about RFA and point to inconsistencies and open questions.
\end{abstract}

JEL codes: E42, E51, E58, E61, E63, H63

Keywords: Central bank digital currency, Fedcoin, CADcoin, e-krona, e-Peso, J Coin, reserves for all, deposits, narrow banking, cash, equivalence, central bank, lender of last resort, politico-economic equivalence

*For discussions on the subject and/or comments on earlier drafts, I thank Ernst Baltensperger, Markus Brunnermeier, Stijn Claessens, Egemen Eren, Petra Gerlach, Thomas Jordan, Carlos Lenz, Cedric Tille, Fritz Zurbrügg, and conference participants. I am grateful to Morten Bech for sharing the money flower diagrams.

†Study Center Gerzensee; University of Bern; CEPR; CESifo. P.O. Box 21, CH-3115 Gerzensee, Switzerland. dirk.niepelt@szgerzensee.ch, www.niepelt.ch. 


\section{Contents}

1 Introduction $\quad 3$

2 Electronic Central Bank Money 4

2.1 Types of Money . . . . . . . . . . . . . . . . . . . . . 4

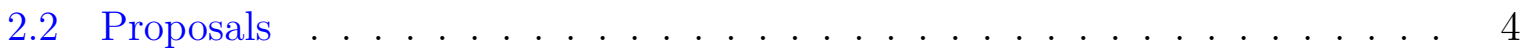

2.3 Reserves for All . . . . . . . . . . . . . . . . . . . . 6

3 Related Debates $\quad 8$

3.1 Narrow Banking Proposals . . . . . . . . . . . . . . . . . . 8

3.2 Proposals to Abolish Cash . . . . . . . . . . . . . . . . . . . . . . . 9

4 Neutrality $\quad 10$

4.1 Store of Value . . . . . . . . . . . . . . . . . . . . . . . . 11

4.2 Means of Payment . . . . . . . . . . . . . . . . . . . . 12

4.3 Neutrality Proposition . . . . . . . . . . . . . . . . . 13

5 Non-Neutrality $\quad 14$

5.1 Information . . . . . . . . . . . . . . . . . 15

5.2 Bank Incentives . . . . . . . . . . . . . . . . . . . . . . . 15

5.3 Government Incentives . . . . . . . . . . . . . . . . . . . . 16

6 Other Implications $\quad 18$

6.1 Financial Stability . . . . . . . . . . . . . . . . . . 18

6.2 Credit . . . . . . . . . . . . . . . . . . 19

6.3 Monetary Policy . . . . . . . . . . . . . . . . . . . . . . . . . . 19

6.4 Structural Changes . . . . . . . . . . . . . . . . . . . . 20

7 Conclusion $\quad 20$ 


\section{Introduction}

Far into the twentieth century central banks commonly offered accounts not only to a select group of financial institutions but also to non-banks (BIS, 2018). This liberal approach has given way to a monetary arrangement where the general public typically uses only one form of central bank issued money, namely cash. Access to electronic central bank money - "reserves" - generally is restricted to financial institutions whom the central bank interacts with to implement monetary policy. When households or nonfinancial firms pay electronically they use privately issued money (e.g., bank deposits), not central bank money.

The advantages and disadvantages of this monetary arrangement are the subject of an intensifying debate which takes place against the background of fundamental changes in the financial system (including technological innovations, the entrance of new players ["fintech" and "bigtech"], new payment systems) as well as questions about the future of cash and interest in private digital tokens like Bitcoin (BIS, 2018). At the same time, the debate testifies to a loss of trust in traditional banks after the recent financial crisis and an increasingly critical attitude towards their role in money and credit creation. While this attitude has only recently gained prominence in the political arena-most notably in the Swiss constitutional referendum on "Vollgeld" (sovereign money) 1 - it is much older and precedes the recent changes in technology and market structure (e.g., Fisher, 1935; Tobin, 1985).

In this paper, I offer a macroeconomic perspective on the implications of letting the general public access central bank money in electronic form- "Reserves for All" (RFA). Except for a clarification of the terminology used and a brief discussion of elementary features of electronic central bank money (in section 2) I do not emphasize technological aspects. Instead, I focus on the key macroeconomic question of interest, namely the difference between bank issued "inside" and central bank issued "outside" money, e.g., RFA.

In section 3, I distinguish the RFA proposal from related, but conceptually different proposals to introduce narrow banks or restrict the use of cash. In section 4, I lay out an equivalence result according to which a substitution of outside for inside money is neutral: When a fiscal-monetary policy implements an "initial" equilibrium with inside money then an alternative fiscal-monetary policy with more outside money and with transfers implements a "new" equilibrium with the same allocation and prices and less inside money. This suggests negligible macroeconomic effects of RFA.

But as I discuss in section 5, the neutrality proposition relies on conditions relating to bank and government (central bank) incentives which are likely violated. Against this background I assess in section 6 the plausibility of various suggested implications of RFA, including effects on financial stability, national saving and investment, and the conduct of monetary policy. I conclude in section 7 that some suggested implications are at odds with my analysis and that the policy discussion so far has been missing important elements.

\footnotetext{
${ }^{1} \mathrm{On}$ the Swiss "Vollgeld" initiative, see www.vollgeld-initiative.ch/english/. See www.sovereignmoney.eu and internationalmoneyreform.org for the policy discussion in other countries including Iceland and The Netherlands.
} 


\section{Electronic Central Bank Money}

\subsection{Types of Money}

Bech and Garratt (2017) propose a taxonomy of money that distinguishes monies along four dimensions. The first dimension concerns the issuer - money may be issued by the central bank, a commercial bank, or other private issuers - and the second dimension relates to the form of money - electronic or physical. The third dimension pertains to the set of agents that have access: access can be universal or limited, for instance to financial institutions. Finally, the fourth dimension concerns the degree of centralization of the transfer mechanism: A central bank reserves settlement system typically is more centralized than the mechanism through which cryptocurrency tokens are transferred. The degree of centralization closely relates to the distinction between token- and accountbased systems and correspondingly, the need to verify objects versus account holders (BIS, 2018).

Other dimensions of relevance for electronic central bank money concern the question, when the money can be used for payments (always, only during restricted hours, or just intraday); whether it can be used anonymously; and whether it pays interest and if so, how much (BIS, 2018). The last point connects to the broader issue of whether different types of central bank money (electronic or not) can and should be tradable against each other or whether markets can and should be segmented. ${ }^{2}$

Bech and Garratt (2017) illustrate their taxonomy by way of a "money flower", see figures 1 and 2. Bech and Garratt (2017) are primarily interested in decentralized types of central bank money for peer-to-peer transactions, which they refer to as central bank cryptocurrencies. ${ }^{3}$

\subsection{Proposals}

The "Fedcoin" proposal of a USD-based central bank cryptocurrency for retail use is due to Koning (2014). Andalfatto (2015) is supportive and argues that it should be possible to transact anonymously to ensure that the retail central bank cryptocurrency matches the benefits of cash. Raskin and Yermack (2016) consider challenges for central banks posed by private cryptocurrencies (similar to the challenges posed by dollarization), and they discuss how a central bank digital currency paying interest could change banking and monetary policy.

Proposals for central bank cryptocurrencies for wholesale use include the CAD-based "CADcoin" and a SGD-based model. A first round of assessments has not produced clear

\footnotetext{
${ }^{2}$ Could some groups be prevented from holding certain forms of central bank money, or from holding them beyond a certain limit? Or should central bank monies be freely exchangeable against each other, possibly at flexible exchange rates?

${ }^{3}$ Bech and Garratt (2017) emphasize anonymity and improved efficiency, respectively, as the key features of central bank cryptocurrencies for retail and wholesale use. They argue that a non-anonymous central bank cryptocurrency for retail customers would "simply" amount to letting the public open accounts at the central bank. For wholesale customers with (non-anonymous) access to central bank reserves a central bank cryptocurrency would only add value if it improved efficiency.
} 


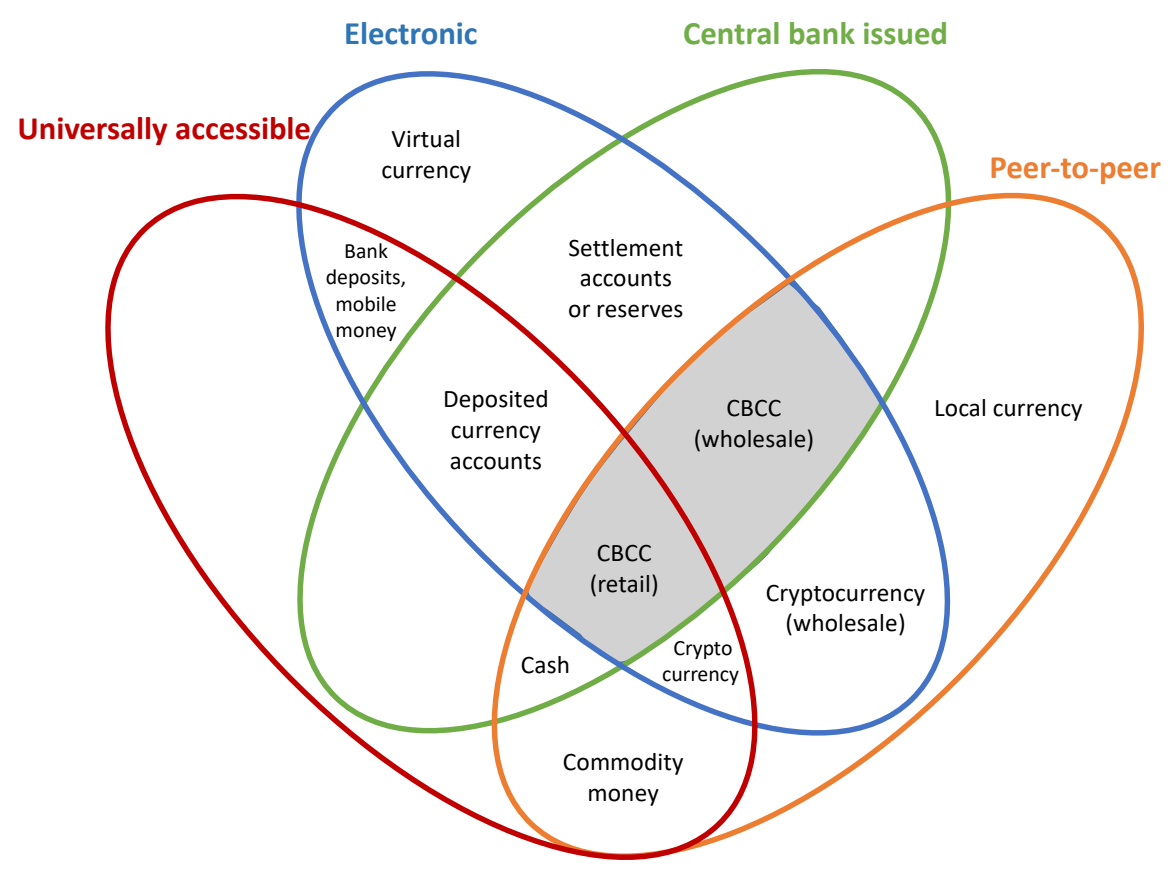

Figure 1: The money flower: A Taxonomy of Money (Bech and Garratt, 2017).

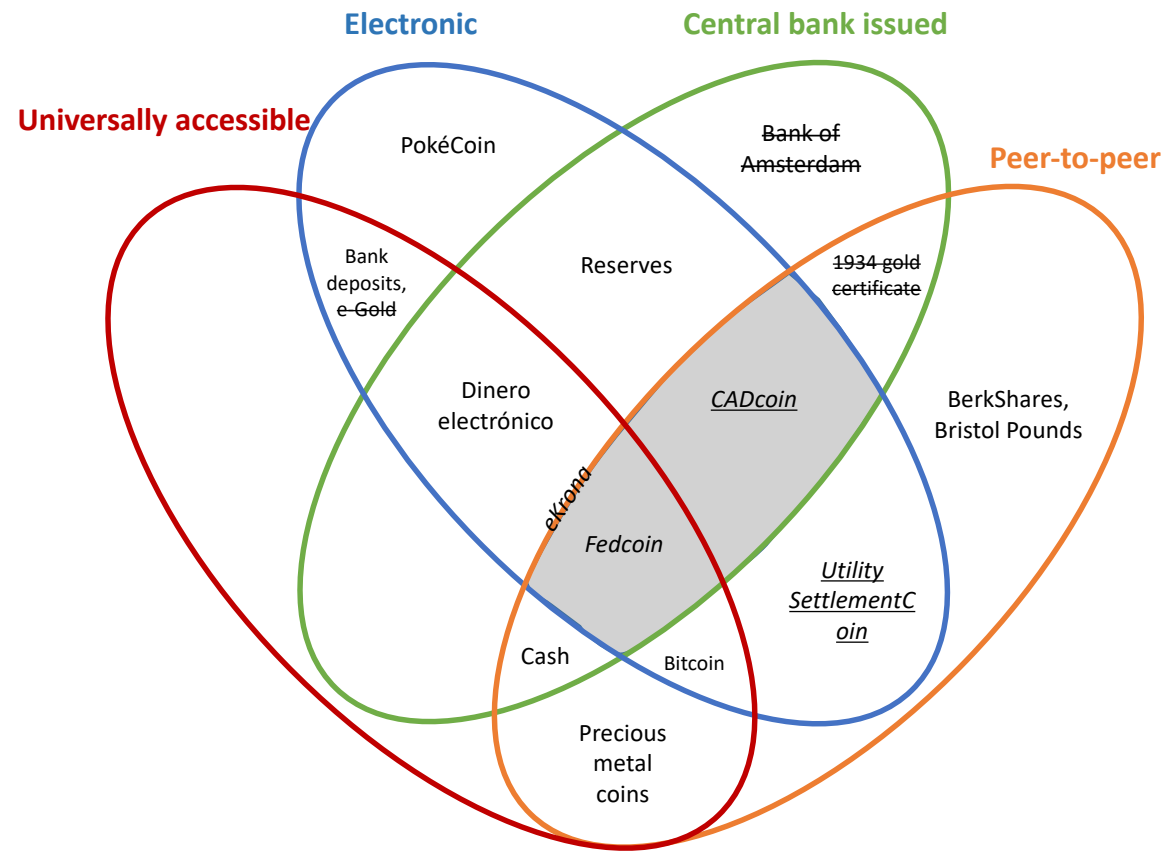

Figure 2: The money flower: Examples (Bech and Garratt, 2017). 
evidence that would point to significant efficiency gains relative to existing, centralized payment systems unless the cryptocurrency were embedded in a larger "ecosystem" of market infrastructures (Chapman, Garratt, Hendry, McCormack and McMahon, 2017; Monetary Authority of Singapore, 2017; BIS, 2018). ${ }^{5}$

The Swedish "e-krona" project is motivated by concerns about the disappearance of cash as well as diminished competition among payment providers and reduced robustness of the payment system which could arise as a consequence (Sveriges Riksbank, 2017). ${ }^{6}$ While a final decision on the project is yet outstanding a preliminary proposal foresees a widely accessible, real time system for small payments; with no interest accruing on e-krona accounts, but with the possibility to introduce interest payments (or charges) in the future; and with potential options including an account- or "register-based" solution, or a "value-based" solution for offline payments that is based on an app or a payment card and that would more closely resemble cash (Sveriges Riksbank, 2017).

In 2017-2018, the Banco Central del Uruguay successfully tested an anonymous but traceable "e-Peso" for consumers which allowed for one-to-one conversion between cash and the electronic means of payment. ${ }^{7}$

In Japan, a consortium of commercial banks plans to introduce a digital currency, "J Coin," by 2020. The currency would trade at par with the JPY and the app-based service would be provided "for free," in exchange for user data. The central bank and the financial regulator support the project. ${ }^{8}$

\subsection{Reserves for All}

In the following, I adopt a broader perspective. Rather than restricting attention to central bank monies based on cryptocurrencies or other specific technologies I consider

\footnotetext{
${ }^{4}$ Chapman et al. (2017) argue that "[f] or critical financial market infrastructures, such as wholesale payment systems, current versions of DLT [distributed ledger technology] may not provide an overall net benefit relative to current centralized systems. ... Benefits for the financial system of a DLT-based wholesale payment system could likely arise from its interaction with a larger DLT ecosystem of financial market infrastructures, potentially including cross-border transactions." See also Payments Canada, Bank of Canada and R3 (2017).

${ }^{5}$ In contrast to central bank cryptocurrencies for wholesale use such as CADcoin, the "Utility Settlement Coin" model promoted by several commercial banks operates independently of the central bank: "USC is an asset-backed digital cash instrument implemented on distributed ledger technology for use within global institutional financial markets. ... USC is fully backed by cash assets held at a central bank. ... launched the concept in September 2015 to validate the potential benefits of USC for capital efficiency, settlement and systemic risk reduction in global financial markets" (UBS, 2016).

${ }^{6}$ Fears about the disappearance of cash may be premature as resistance appears to be growing, see www.kontantupproret.se.

${ }^{7}$ Information provided by the Bank's deputy governor at the SUERF/Bocconi Conference on "Do we need central bank digital currency? Economics, technology and psychology," 7 June 2018, Milan.

${ }^{8}$ See "Japan's big banks plan digital currency launch," Financial Times, 26 September 2017.
} 
arbitrary forms of centrally managed, electronic central bank money. ${ }^{9} 10$ The key aspect I am interested in is universal access that is, the possibility for the general public to use electronic central bank money. ${ }^{11}$ The system I consider, then, is a system where reserves serve as unit of account, store of value, and means of payment not only for institutions in the financial sector, as they do today, but also for households and firms outside of that sector.

With this focus on universal access in mind I do not take a stance on technical aspects such as whether payments would be made using a traditional payment system or a distributed ledger; and whether RFA would be held in a central bank account; an off-balance-sheet account managed by a service provider on the basis of a public-private partnership; or on a prepaid card. From a macroeconomic perspective these considerations are of second or third order even if they are of first-order importance for many operational, legal, and technical questions. ${ }^{12}$

The proposal to make central bank issued digital money accessible to the general public in order to provide a partial substitute for cash on the one hand and bank deposits on the other dates back a long time. Most notably, Tobin $(1985 ; 1987)$ promotes the idea. Recent discussions include Groff (2013), Koning (2014), and Niepelt (2015). ${ }^{13}$

Tobin (1985) emphasizes the benefits for society of having access to electronic means of payment (as opposed to cash only) and being able to rely on a robust payments system. He argues that institutional features that promote robustness, for example deposit insurance, require regulatory limits on competition and he asks how to "strike a balance between competitive efficiency and the protection of depositors (p. 25)." Against this background, he suggests that "[d]eposited currency-100\%-reserve deposits - payable in notes or coin on demand, transferable by order to third parties, secure against loss or theft, would be a perfect store of value in the unit of account (p. 25)."

Similarly, Tobin (1987) proposes "deposited currency accounts." He writes (pp. 172173):

\footnotetext{
${ }^{9}$ Against the background of the existing regulatory framework that was established to fight money laundering, tax evasion, and other illicit activities it is unlikely anyway that central banks would issue electronic means of payment that could be used anonymously (BIS, 2018; Berentsen and Schär, 2018).

${ }^{10}$ Barrdear and Kumhof (2016) attempt to quantify the effect of introducing an interest-bearing, universally accessible, electronic central bank liability backed by government bonds and implemented via distributed ledgers. Based on a calibrated model they argue that GDP permanently rises by up to $3 \%$, and interest rates, tax distortions, and transaction costs fall; the new liability also introduces an additional policy instrument. "On the negative side, there remains a clear concern with the proper management of the risks involved in transitioning to a different monetary and financial regime" (Barrdear and Kumhof, 2016, p. 3).

${ }^{11}$ One might argue that electronic central bank money already serves today as means of payment for retail use because a customer payment from one commercial bank to another is settled with central bank money. However, the difference is that in the current system, customers must hold private bank deposits (and typically do so for an extended period) before they can use them to make a payment.

${ }^{12}$ For a discussion of legal aspects pertaining to RFA under Swiss law, see Reiser and Wyss (2018).

${ }^{13}$ Groff (2013) envisions a form of digital cash that is available to users free of charge, subject to no transaction fees, bearing no interest. See also Motamedi (2014). Many additional contributions discuss RFA against the background of proposals to relax the effective lower bound on interest rates, see the discussion in section 3 .
} 
"I think the government should make available to the public a medium with the convenience of deposits and the safety of currency, essentially currency on deposit, transferable in any amount by check or other order. This could be done in one or more or the following ways:

(a) The Federal Reserve banks themselves could offer such deposits, a species of "Federal Funds." Presumably they would establish conveniently located agencies in private banks or post offices. The Federal Reserve banks would pay for the services of the agents. Potential agents could bid for the contracts. Transactions between holders of deposited currency accounts, or between them and, directly or indirectly, other Federal Funds accounts would be cleared through the Federal Reserve. Wire transfers, as well as checks, would be possible. Giro-type payment orders to other accounts in the system could be made. Overdrafts would not be allowed. Computer capabilities should soon make it possible to withdraw conventional currency at any office or agency, and even to order payments to third parties by card or telephone. Interest at a rate sufficiently below the rates on Treasury securities to cover costs could be paid, and some costs could be charged to accountholders.

(b) Banks and other depository institutions could offer the same type of account, or indeed be required to do so. The deposited funds would be segregated from the other liabilities of the institution, and invested entirely in eligible assets dedicated solely to those liabilities. These would be Federal Funds or Treasury obligations of no more than three months maturity. As in case (a), interest might be paid on Federal Funds in such segregated portfolios.

In either case, deposited currency accounts would not, have to be insured against illiquidity or insolvency, only against malfeasance by the agent or depository, a much smaller risk. Thus, a part of the payments system would be secure without the help of deposit insurance. Members of the public who value the security of currency at sacrifice of interest, largely the poorer and less sophisticated population, would be accommodated. Moreover, assuming statutory limits on insurance of other deposits are made effective, depositors who wish safety and liquidity on larger sums would be served."

\section{Related Debates}

Proposals to introduce RFA often are combined with suggestions to introduce narrow banking or restrict cash use. These three proposals are logically distinct.

\subsection{Narrow Banking Proposals}

Many economists, central bankers, and practitioners voice concerns that the ability of commercial banks to "transform maturity" and create money causes fragility and instability. 
The "Chicago plan" from the 1930s proposes to end fractional reserve banking and thus, to separate credit from money creation (Fisher, 1935; Fisher, 1936). Benes and Kumhof (2012) revisit the Chicago plan and offer a quantitative assessment; they argue that the plan would improve outcomes. Similar to the Chicago plan, the Swiss "Vollgeld" initiative proposes a complete ban on private money creation.

Kay (2009) argues that financial regulation and supervision in the run-up to the recent financial crisis has failed and that complex regulatory frameworks should make way for simple structural rules and a "firewall between retail deposits and other liabilities of banks." Kotlikoff and Goodman (2009) and Kotlikoff (2010) go further and propose a system of "Limited Purpose Banking," in which financial intermediaries are reduced to managers of equity financed mutual funds invested in financial assets. Melaschenko and Reynolds (2013) propose a resolution mechanism that shares features of equity financing. ${ }^{14}$

King (2016) proposes that all short-term bank liabilities should be covered by liquid assets and a central bank credit line that depends on the quantity and quality of assets lodged at the central bank to serve as collateral when needed.

McMillan (2014) emphasizes that many proposals to implement narrow banking restrictions pose the problem that they require regulators to distinguish between financial and non-financial companies, which could be difficult in practice; as a consequence, banks might circumvent the restrictions. As a solution to this problem, McMillan (2014) proposes a rule according to which the market value of any company's real assets always must exceed the value of its liabilities that is, financial assets always are financed by equity. ${ }^{15}$

These proposed arrangements differ from RFA because RFA does not directly constrain the business model of banks or their ability to create inside money. RFA simply provides the public with an electronic means of payment that serves as an alternative to deposits and other forms of private money.

\subsection{Proposals to Abolish Cash}

Proposals to abolish cash or eliminate large denomination typically derive from two motivations. First, to increase the cost of criminal, black market, or money laundering activities as well as tax evasion (see, for example, Rogoff, 2016). And second, to enlarge the set of monetary policy options.

How convincing the first motivation is, is a matter of debate. The extent to which cash use fosters crime and illegal activities is unclear, as is the trade-off between the benefit of crime reduction and the cost that cash restrictions create for legitimate activities (McAndrews, 2017). ${ }^{16}$ Moreover, restricting cash use would (further) undermine privacyand privacy has both private and social value (Kahn, McAndrews and Roberds, 2005). In any case, abolishing cash would be difficult because in a free society, any government-led

\footnotetext{
${ }^{14}$ According to the proposal, a failing bank is solidly re-capitalized by means of a bail-in. The shareholders and junior creditors become the owners (with the seniority structure preserved) of a newly created holding company that owns the re-capitalized bank. The proposal assures that the re-capitalization occurs over a weekend; the bank continues to operate without interruption; it can immediately issue new debt; and the owners of the bailed-in debt recover the value of their claims.

${ }^{15}$ For a brief discussion of other contributions to the narrow banking debate, see Niepelt $(2014 a)$.

${ }^{16}$ Abolishing cash could also negatively impact financial literacy.
} 
reform of the monetary system is constrained by the requirement that government money must remain attractive for its users.

The second motivation has deficiencies as well. Its starting point is the observation that banks issuing deposits cannot lower the deposit rate significantly below zero without risking large scale cash withdrawals and thus, the stability of the institution. The effective lower bound on the deposit rate implies, in turn, an effective lower bound on the central bank's policy rate unless the central bank is willing to accept a compression of the interest rate spread earned by financial institutions, with negative consequences for bank profitability and potentially, financial stability. ${ }^{17}$ An abolishment or taxation of cash, or restrictions on its use would limit the outside options for depositors and this would open the way for more aggressive monetary policy interventions. ${ }^{18}$

But a more aggressive monetary policy stance is possible, in principle, even without legal restrictions on cash use. Goodfriend (2000) proposes a carry tax on monetary liabilities - effectively a negative interest rate on cash - to relax the lower bound on deposit rates. ${ }^{19}$ Buiter $(2009 a ; 2009 b)$ identifies the bearer security nature of currency (i.e., the fact that the owner of cash remains anonymous) as the fundamental cause of the lower bound on nominal interest rates. He proposes two alternative strategies in addition to taxing currency (which poses incentive problems), to relax the bound. First, to abolish currency. And second, to float the exchange rate between cash and reserves. In the process, the medium of exchange and unit of account functions of money would be unbundled. Monetary policy would be conducted as usual by setting interest rates on reserves but positive (negative) interest rates on reserves would be associated with an appreciation (depreciation) of cash. ${ }^{20} 21$

In conclusion, the RFA proposal is fundamentally unrelated to the question of whether cash should be abolished or its use discouraged. Even if RFA were motivated by the aim to empower monetary policy this could be achieved without abolishing cash or restricting its use.

\section{Neutrality}

To organize the discussion of possible consequences of RFA, I propose a neutrality result according to which inside money is irrelevant from a macroeconomic point of view. An implication of the result is that the introduction of RFA and its substitution for inside

\footnotetext{
${ }^{17}$ The compression is moderated when the central bank only charges negative interest on balances that exceed exemption thresholds, as is current practice in Switzerland (see https://www.snb.ch/en/ifor/finmkt/operat/id/finmkt_nz).

${ }^{18}$ Fiscal policy (e.g., time varying consumption taxes) offers alternative means to manipulate the real interest rate.

${ }^{19} \mathrm{He}$ also proposes quantitative easing and money transfers as alternative policy instruments.

${ }^{20}$ Buiter argues that while the second strategy suffers from the risk that the numéraire could "follow the currency" (users could quote prices in cash which would undermine the objective), governments have instruments to reduce this risk, for instance by requiring taxes to be paid in reservers rather than cash.

${ }^{21}$ Many authors have followed up on this or related suggestions and related it to RFA-like proposals. See, for example, Kimball (2013) and Kaminska (2014). For a brief discussion of other contributions to the debate, see Niepelt $(2014 b)$.
} 
money does not have macroeconomic consequences. After laying out the logic of the argument in this section I turn in section 5 to a discussion of key assumptions underlying its validity. In section 6 , I confront the findings with arguments commonly made in discussions about RFA.

The neutrality result is in the spirit of Modigliani and Miller (1958), Barro (1974), Wallace (1981), or Chamley and Polemarchakis (1984). ${ }^{22}$ Its purpose is to provide a benchmark, not the most realistic description, in order to identify key conditions for neutrality and thus, potential sources of non-neutrality. The macroeconomic perspective I adopt leads me to emphasize the economy's aggregate balance sheet (or consolidated intertemporal budget constraint). This contrasts with partial equilibrium intuitions inspired by models in the tradition of Diamond and Dybvig (1983) which underly many arguments in the debate.

The basic intuition for the result is as follows: Inside money serves various functions in the non-bank sector. RFA, possibly accompanied by fiscal interventions, can also serve these functions. Inside and outside money thus can be substituted against each other, subject to appropriate fiscal interventions, without macroeconomic consequences.

Money serves as a unit of account; a means of payment to mitigate the double coincidence of wants problem; and thus, also as a store of value. Since central bank money - cash or reserves at the central bank - serve as the unit of account a substitution of outside for inside money does not affect the first of the mentioned functions. I therefore focus on the role of money as a store of value or means of payment. Moreover, I restrict attention to inside money - bank deposits - that are not "backed" by outside money in the banks' balance sheets (that is, I focus on the deposits that drive the money multiplier above one). The share of inside money that is "backed" by outside money could be taken off the banks' balance sheets and thus, replaced by outside money without macroeconomic consequences.

\subsection{Store of Value}

Money serves as a store of value because it is a financial claim. But this claim does not affect aggregate wealth. An economy's wealth comprises the assets in the consolidated balance sheet, representing the economy's productive capacity, endowments, and net external assets. The liability side of the consolidated balance sheet determines how this wealth is apportioned and distributed among the various sectors and agents in the economy, but it does not affect its size (cf. also Modigliani and Miller, 1958). Whether the central bank issues outside money or the banking sector inside money thus is irrelevant for aggregate wealth.

The composition of the stock of money might, however, be relevant from a distributional point of view, for example because inside and outside money have different payment characteristics, or because their tax treatments differ. These distributive implications of a substitution of outside for inside money can be sterilized by appropriate state contingent transfers. $^{23}$

\footnotetext{
${ }^{22}$ For a textbook treatment of neutrality results, see Sargent $(1987,5.4)$.

${ }^{23}$ Of course, the transfers and their financing need to be non-distorting for equivalence to hold, cf.
} 
A counterargument to this reasoning emphasizes "crowding out," namely the fact that for given private sector saving, additional public sector debt issuance (including outside money issuance) reduces the share of private saving that funds physical investment. When inside money (which is an asset and a liability of the private sector) does not increase private sector wealth but outside money (which is an asset of the private sector but a liability of the public sector) does, as the counterargument asserts, then inside money creation is associated with a smaller wealth effect in the private sector than outside money creation and as a consequence, with less aggregate consumption and crowding out.

This counterargument neglects the fact that the economy's consolidated balance sheet includes the public sector that is, the public sector's net worth is a component of national wealth. Since the private sector "owns" the public sector as taxpayers ultimately are responsible for covering public sector deficits, public debt (including outside money) does not increase private sector net worth (Barro, 1974), and this implies that inside and outside money do not have differential aggregate wealth effects. Of course, with heterogeneous groups in society (e.g., different cohorts), crowding out does occur to the extent that debt issuance and the associated change in the timing of taxation redistributes the tax burden across groups with different marginal propensities to save (Diamond, 1965; Niepelt, 2004). But this redistribution can be offset by appropriate transfers between the affected groups.

\subsection{Means of Payment}

To assess whether outside money can substitute for inside money as a means of payment consider the extreme case of a complete replacement that is, a requirement that all payments must be conducted using central bank money. Holding velocity constant, this would require that the share of deposits currently used for payments (rather than held for precautionary reasons) was replaced by central bank money, for example by having banks sell a corresponding amount of assets to the central bank in exchange for reserves.

In effect, banks would replace loans or other financial assets on their balance sheet with reserves and as a consequence, the share of deposits currently used for payments would be fully "backed" by these reserves - a situation akin to having non-banks use reserves as means of payment. Equivalently, households would substitute RFA for deposits and the central bank would provide loans to the banks that are secured by bank assets. ${ }^{24} \mathrm{In}$ either case, the quantity of central bank money would increase relative to the situation before the financial crisis when banks held few reserves in excess of what was needed to settle net payments between them. And the degree of "maturity transformation" in the banking sector would be reduced.

The more limited extent of "maturity transformation" would have distributive implications because banks would earn a lower spread on their assets net of liabilities. To offset these implications the central bank would refund to the banks the seignorage profits that banks generate in the current setting but would loose under the new balance sheet structure. Banks' profit streams thus would remain unchanged. As would be the pro-

\footnotetext{
Barro (1979).

${ }^{24}$ See BIS (2018, Annex B) for an illustration of the associated changes in the balance sheets of banks, the central bank, and households.
} 
cess of credit extension. Banks would continue to screen and select projects that receive financing before selling the loans on to the central bank or financing them with central bank funding. At no time would the central bank be in the business of directly extending credit to the "real" economy.

The modified balance sheet structure of banks and the compensating transfers from the central bank would render explicit what is implicit in the current monetary system: The implicit lender-of-last-resort (LOLR) guarantee provided by the central bank; and the value of that guarantee. ${ }^{25}$

One might argue that the central bank's implicit LOLR guarantee is much smaller than suggested above, because LOLR assistance is granted only occasionally, and in amounts that are much smaller than the share of deposits used for payments. But this is not clear. The current monetary system relies on the strong perception in the non-bank sector that inside money constitutes a secure claim on central bank money. The deposit insurance system and more importantly, actual LOLR assistance in crisis times; bank supervision; and various other types of assurances by government foster this perception of a fixed exchange rate between inside money in the regulated banking sector and outside money.

If the perception indeed was wrong, and the assurances misleading, then the implicit guarantee would indeed be smaller than suggested. A neutral substitution of outside for inside money then would require, not an unconditional sale of assets to the central bank (or secured borrowing from the central bank) but rather a contingent "liquidity line." 26

\subsection{Neutrality Proposition}

I have argued that both from an aggregate balance sheet point of view and as far as money's means-of-payment function for the non-bank sector is concerned, starting from an equilibrium, a substitution of outside for inside money accompanied by appropriate transfers leaves macroeconomic outcomes unaffected. ${ }^{27}$ I have not argued, however, that this substitution is consistent with optimality on the part of the parties that issue money, namely the central bank and commercial banks (see section 5). The neutrality proposition suggested by the preceding discussion thus is a conditional one. Related, I have also not argued that arbitrary compositions of money can be implemented as equilibrium outcomes.

\footnotetext{
${ }^{25}$ Again, there are parallels to public debt whose dominant component in many countries is implicit. See Auerbach, Gokhale and Kotlikoff (1994) for a theoretically sound approach to measuring public debt. Estimated levels of implicit government debt in the European Union are large. According to Kaier and Müller (2015), accrued-to-date implicit pension liabilities in 18 member countries of the European Union ranged, in the year 2006, from 125 (Latvia) to 362 (France) percent of GDP. For broader measures of the "sustainability" of public finances in the European Union, see for example European Commission (2016).

${ }^{26}$ Tobin $(1985$, p. 24 ) appears to subscribe to the view that implicit guarantees are a reality and that they are large when he states that "[d]eposit insurance ... is a massive extension and delegation of the government's monetary fiat - a blank check, so to speak, which might be an enormous obligation in some contingencies." Similarly, King (2016) argues that central banks are condemned to provide liquidity assistance to banks in crisis. He seems to doubt, however, that the "alchemy" that runs through the financial system to transform maturities and liquidity is well understood.

${ }^{27}$ The prices of commodities, financial claims, and "liquidity" in the two equilibria are the same as well.
} 
Let $M$ denote a sequence of outside money supplies; $N_{i}$ a sequence of "unbacked" inside money supplies by bank $i$; $\tilde{N}_{i}$ the portion of the latter sequence effectively used for payments; and $L_{i}$ a sequence of other liabilities of bank $i{ }^{28}$

Proposition Consider an "initial" fiscal-monetary policy with outside money $M^{\star}$ that supports an equilibrium with unbacked inside money $\left\{N_{i}^{\star}\right\}_{i}$, of which $\left\{\tilde{N}_{i}^{\star}\right\}_{i}$ is used for payments, and other bank liabilities $\left\{L_{i}^{\star}\right\}_{i}$.

- Fix a balance sheet structure of banks that differs threefold from the structure in the initial equilibrium: First, $\left\{\tilde{N}_{i}^{\star}\right\}_{i}$ is replaced by $\{0\}_{i}$. Second, $\left\{L_{i}^{\star}\right\}_{i}$ is replaced by $\left\{L_{i}^{\star}+N_{i}^{\star}-\tilde{N}_{i}^{\star}\right\}_{i}$. And third, (non-reserve) bank assets are reduced by the amounts $\left\{\tilde{N}_{i}^{\star}\right\}_{i}$.

- Consider a "new" fiscal-monetary policy with outside money $M^{\star}+\sum_{i} \tilde{N}_{i}^{\star}$, additional central bank assets $\sum_{i} \tilde{N}_{i}^{\star}$, and additional transfers from the government to banks and possibly, between groups in the private sector. The transfers assure that, at the initial equilibrium prices and returns and given the new balance sheets, all groups in the private sector, including banks, generate the same after-tax incomes as in the initial equilibrium.

Then, the new policy implements an equilibrium in the non-bank private sector, conditional on the new bank balance sheets. The allocation and prices in this equilibrium coincide with the allocation and prices in the initial equilibrium.

In the following, I refer to the new policy that implements the equilibrium with the initial allocation as the equivalent policy.

Note that an immediate implication of the proposition is that the introduction of RFA is neutral as long as reserves perform the same payment functions for non-banks as deposits do. Note also that the result can be extended to cover stochastic environments. When $\tilde{N}_{i}^{\star}$ is stochastic then it suffices for the maximum of $\sum_{i} \tilde{N}_{i}^{\star}$ over all states of nature to be converted into central bank money. Insurance contracts between banks, or a money market together with side payments, can take care of the allocation of central bank money among banks.

\section{Non-Neutrality}

The result proposed in section 4 suggests three key conditions that have to be satisfied for neutrality to prevail and thus, for a partial substitution of outside for inside money to have no macroeconomic consequences. One condition relates to information, the other two to incentives.

\footnotetext{
${ }^{28}$ Without loss of generality we abstract from different types of other liabilities. Similarly, we abstract from heterogeneity within bank assets other than capital vs. reserves.
} 


\subsection{Information}

On a fundamental level, money is a substitute for a public monitoring system - a record keeping device (Kocherlakota, 1998). Since these records can be kept in a decentralized, bank-run system or in a centralized, central-bank-run system the record keeping function per se does not undermine the neutrality claim. The acquisition of information, however, might be more difficult in a centralized system. When weighing whether to create inside money or not, banks base their decisions on "knowledge of the particular circumstances of time and place" (Hayek, 1945); this knowledge could be difficult to communicate in time to a central decision maker (the central bank) even when the latter had local agents that collected the information on his behalf.

Convincing as this reasoning appears at first sight it depends on the assumption that price signals on functioning markets cannot fully convey local information. But it is not clear why this should be the case with RFA. After all, a monetary system with RFA would not constitute a "planned economy:" Price signals from money markets would continue to communicate information to the central bank as they do today, and private agents would continue to be able to respond to these signals.

If the information acquisition capacity of the economy nevertheless suffered with less inside money creation, how large would the effects be? It seems likely that the marginal loss of local knowledge would accelerate with an increasing substitution of outside for inside money that is, the information related cost of the substitution would be convex. A marginal substitution of RFA for inside money therefore would have minor macroeconomic implications. ${ }^{29}$

\subsection{Bank Incentives}

A general argument against the irrelevance of a firm's liability structure relates to the fact that this structure affects the incentives of owners or managers (for an overview, see Tirole, 2006). Similarly, changes in the balance sheet structure of banks might undermine, or strengthen incentives and this might affect the equilibrium allocation.

Most importantly, the incentives for banks to exert sufficient screening and monitoring efforts might suffer. A substitution of reserves for loans on the asset side of banks' balance sheets might give rise to an "originate-to-distribute" business model in which banks extend credit to non-banks before selling the loan to the central bank. This might reduce incentives to carefully screen projects and could have important negative mediumand long-term effects on the economy's development. It could also affect the wealth distribution between the public and private sector (central bank vs. commercial banks). ${ }^{30}$

How strong these effects would be, and whether they would indeed result in weaker incentives is unclear as this would depend on the regulatory framework. After all, depositors do not currently play any meaningful monitoring role but rely on the efforts of

\footnotetext{
${ }^{29}$ If the convexity assumption were correct it would imply that the information processing capacity of an economy with inside money and some RFA significantly exceeded the capacity in an economy where inside money has been banned.

${ }^{30}$ Incentives would similarly be negatively affected if banks continued to keep the loans on their balance sheets and used them as collateral for central bank funding rather than financing their assets with deposits.
} 
the central bank, the banking supervisor, the deposit insurance agency, the consumer protection agency, etc. The latter actors would continue to be active in their present roles and in particular, the central bank would have even stronger incentives than today to supervise banks' lending practices as it would acquire (or accept as collateral) more bank loans than in the present system.

In conclusion, there is a case to be made for changed incentives as a consequence of modified bank balance sheet structures, but the exact form and implications are far from clear and certainly strongly dependent on the regulatory environment.

\subsection{Government Incentives}

The neutrality proposition envisions an exogenous new fiscal-monetary policy. It thus abstracts from politico-economic frictions and assumes commitment. Both assumptions are unrealistic.

Consider first the political support for transfers. I have argued above that a neutral change of fiscal-monetary policy would render the implicit LOLR guarantees provided by the central bank as well as their values under the current monetary arrangement explicit. But it is unlikely that the beneficiaries of these guarantees, once made explicit, would continue to be able to muster the same political support. In other words, the equivalent fiscal-monetary policy most likely would not be an equilibrium policy. ${ }^{31}$ In politicoeconomic equilibrium, the now explicit support by the central bank could rise or fall and as a consequence, payment related services could become cheaper or more expensive.

Which of these two outcomes would be more likely depends, among other factors, on the degree of competition in the banking system. When competition is high bank customers rather than shareholders benefit from the implicit central bank subsidy in the current system, and increased transparency coupled with the political influence of, e.g., small and medium sized enterprises might strengthen the political support for central bank support. When competition is low, in contrast, such that the shareholders of banks are the major beneficiaries of central bank support in the current system, then it seems more likely that increased transparency would weaken the political support for banks and their customers and as a consequence, payment related services would become more expensive. This would be associated with lower distortions, however.

The political support would also change for other reasons. Policy choices under commitment typically are not time consistent because the incentives of a government change over time as macroeconomic outcomes that are endogenous ex-ante turn into bygones ex post (Kydland and Prescott, 1982). The initial, equilibrium fiscal-monetary policy in the current policy regime with inside money is time consistent, by assumption, and reflects the ex-post incentive compatibility constraints faced by political decision makers. In a different policy regime with less inside and more outside money, these incentive compatibility constraints would change if the state variables that determine the choice set of political decision makers evolved in different ways. ${ }^{32}$

\footnotetext{
${ }^{31}$ For an overview over models of politico-economic equilibrium, see for example Persson and Tabellini (2000).

${ }^{32}$ See Gonzalez-Eiras and Niepelt (2015) for an analysis of the conditions for equivalence of policy
} 
It seems likely that this would be the case. At the source of the ex-post incentive constraints in the current regime is the fact that private money creation puts the central bank at a second mover disadvantage, effectively forcing it to serve as LOLR during liquidity crises to safeguard the payment system, or even as provider of bailout funds in solvency crises. ${ }^{33}$ According to the neutrality result, the equivalent fiscal-monetary policy would be associated with transfers, including from the central bank to banks (or their customers), and according to the discussion above, these transfers would likely become politically unsustainable once made explicit. As a consequence, bank equity and other state variables would evolve differently and the ex-post optimal government choices in the new regime with less inside and more outside money would differ from the equivalent fiscal-monetary policy.

A different source of potential non-neutrality concerns the central bank's asset management. Under the assumptions underlying the neutrality result the central bank purchases additional assets from the banking sector but it does not directly intervene in the process of credit allocation. Whether this would be incentive compatible ex post is questionable. It is well conceivable that an extension of the central bank balance sheet would lead fiscal policy makers to impose additional constraints on the central bank, for instance to require the bank's investment policy to meet certain "ethical," "social," "ecological," or other standards. In short, credit extension could become more politicized and this might change aggregate investment (see, for example, Kaminska, 2017; Cecchetti and Schoenholtz, 2018).

In conclusion, the political support for the equivalent fiscal-monetary policy would likely differ from the support enjoyed by policy in the current regime and as a consequence, the equivalent policy would not be time consistent. While it is impossible to gauge the properties of the new equilibrium policy outside of a formal model it appears likely that increased transparency would give rise to reduced transfers and less distortions. ${ }^{34}$ At the same time, the risk of political interference with the credit allocation process would likely increase.

regimes and how these conditions depend on the evolution of state variables in politico-economic equilibrium.

${ }^{33}$ While the incentive constraints in the current arrangement tend to increase liquidity and financial support for banks this need not result in excess profits in the financial sector. Depending on the degree of competition, bank customers may be the main beneficiaries. Nevertheless, such support distorts prices, with negative welfare implications.

${ }^{34}$ One might argue that distortions are minimized (maybe to the point that the ex-ante optimal Ramsey (1927) policy becomes implementable) when inside money creation is completely outlawed, as proposed by the sovereign money movement. There is reason to be sceptical. Putting a complete stop to inside money creation would likely not be enforceable. Banks and their clients would search for and find, ways to circumvent the legal prohibition and as a result, the central bank might completely lose control over the money supply. The equilibrium policy would become irrelevant.

A fundamental problem at the source of non-enforceability is the difficulty to define money and what it means to make a payment. "Moneyness" reflects social conventions. Suppose that deposits were outlawed but banks and their customers started to use other bank liabilities with limited price and credit risk as a means of payment. If this practice were outlawed as well, would it also be forbidden to exchange bank liabilities directly, or would that be considered a "payment?" 


\section{Other Implications}

In this section, I review common arguments in the debate on RFA against the background of the discussion in sections 4 and 5 .

\subsection{Financial Stability}

Many commentators argue that the risk of bank runs - sudden withdrawals of depositscould increase when bank customers have the option to convert deposits into RFA rather than just into cash. ${ }^{35}$ This argument is difficult to make sense of within the analytical framework used so far. After all, the neutrality result starts from the presumption that deposits in the current system are implicitly guaranteed by the central bank, so there is no reason to run in the first place (Diamond and Dybvig, 1983) and even if depositors do run, the macroeconomic consequences are minor as the central bank steps in and implicit guarantees simply are made explicit. The same mechanism would continue to operate in the new regime, on a smaller scale (because some inside money would have been made explicit as a consequence of substituting RFA for deposits).

The discussion in section 4 abstracted, however, from physical differences between electronic money and cash; and it therefore cannot speak to the fear of differential risk of "running for RFA" as opposed to cash. ${ }^{36}$ If such differential run risk exists, is it higher with RFA? One group of commentators suggests that this is the case (e.g., Tolle, 2016). The basic idea is that with RFA it becomes easier to shift funds across accounts, and this increases the elasticity of deposit demand. Others are more sceptical. Koning (2018), for instance, retorts that during a confidence crisis bank customers would no longer have to queue to withdraw cash; LOLR support would be provided much more quickly; and large cash holders would continue to shift funds into treasury bills, not into electronic central bank money. As a consequence, the risk of bank runs would decrease rather than increase. $^{37}$

Sveriges Riksbank (2017) similarly expects the introduction of an e-krona to have

\footnotetext{
${ }^{35}$ While RFA might potentially increase the risk of runs for cash, it would not increase the risk of runs with the intention to transfer funds from one bank to another one. The latter risk already is present today. In the Single Euro Payments Area (SEPA) payments up to EUR 15000 are executed within ten seconds; see www.europeanpaymentscouncil.eu on the SEPA Instant Credit Transfer scheme.

${ }^{36}$ Few models can speak to that. A proper theory would have to account for multiple equilibria in spite of the presence of government guarantees; and to be convincing it should take into account how banks optimally respond to such differential run risk, if it exists, (Lucas, 1976).

${ }^{37}$ Koning (2018) argues that, in a world with digital currency, "[i]n the event of a panic, customer redemption requests will be instantaneously granted by the bank facing the run. But that same speed also works in favor of the bank, since a request to the central bank for a top-up of digital currency could be filled in just a few seconds. Since all depositors gets what they want when they want, no lineups are created. And so the viral nature of the panic is reduced. ... In a traditional economy where banknotes circulate, CFOs and the rich dont generally flee into paper money during a crisis, but into short-term tbills. ... Likewise, in an economy where digital currency circulates, CFOs are unlikely to convert deposits into barren digital currency during stress, but will shift into t-bills. The upshot is that banks are not more susceptible to large deposit shifts thanks to the introduction of digital currency - they always were susceptible to digital bank runs thanks to the presence of short-term government debt."
} 
limited effects on financial stability as the Riksbank would continue to engage in the usual LOLR policies. It does see the risk, however, that the substitution of outside for inside money could reduce bank profits and thereby affect banks' stability. This argument assumes that the hidden transfers present in the current system would no longer be present in a system where the central bank's guarantees are made explicit. As I argued in section 5, this is indeed likely.

\subsection{Credit}

Many commentators also suggest that the substitution of outside for inside money could reduce the volume of credit, with important macroeconomic consequences for investment and growth. According to this argument the fact that many banks rely on deposits to finance their assets suggests that less deposit funding would reduce the flow of credit extended by these banks.

However, this argument disregards both liability substitution and securitization: Deposits may be replaced by other forms of bank debt, and loans might be sold to investors. ${ }^{38}$ Under the assumptions underlying the neutrality result banks continue to originate loans even when they have no, or less deposit funding but they sell the loans to the central bank in exchange for reserves or use them as collateral for central bank financing.

As discussed in section 5, the incentive effects of the modified bank balance sheets could lead banks to change their screening and monitoring efforts. But if these efforts indeed weakened and lenders adopted an originate-to-distribute business model then this would likely work in the direction of banks easing credit standards and originating more rather than fewer loans. On the other hand, also as mentioned in section 5, political interference with the central bank's asset management and thus, the central bank's refinancing of bank loans could distort the credit allocation mechanism.

Another argument suggests that additional outside money creation, and the associated lengthening of the central bank balance sheet, would reduce the amount of assets that the private sector may use as collateral (see, for example, Kaminska, 2017; BIS, 2018). The validity of this argument depends on whether banks in the current system do not need to provide collateral in exchange for the implicit central bank guarantees and thus, also, on whether they gamble on receiving LOLR resort even without sufficient collateral.

\subsection{Monetary Policy}

According to the neutrality result, an equivalent fiscal-monetary policy can in principle be implemented. In line with this argument, Sveriges Riksbank (2017) expects limited effects on monetary policy (of the basic e-krona version) and Dyson and Meaning (2018) argue that "with careful design choices, a CBDC need not be disruptive to the conduct of monetary policy."

\footnotetext{
${ }^{38}$ Empirically, the relative importance of bank lending varies across developed economies, in spite of similar institutional environments. This suggests that capital market financing and bank lending indeed are partly substitutable as theoretical considerations imply.
} 
At the same time, however, as argued in section 5, it is questionable whether this equivalent policy would actually be chosen in politico-economic equilibrium. Moreover, a substitution of outside for inside money could change the economic choice set of monetary policy makers, in particular if it were accompanied by restrictions on cash use (a structural change which, as I have argued in section 3, is not inherently connected to the RFA issue). As argued by Bordo and Levin (2017), RFA could then "free" the economy from the lower bound and thereby allow monetary policy to focus on price rather than inflation stability (price level targeting) and to implement the Friedman (1969) rule.

\subsection{Structural Changes}

More generally, the introduction of RFA could give rise to many structural changes whose implications far exceed the scope of the equivalence result. For example, RFA could increase competition in the banking sector. If, as argued by Drechsler, Savov and Schnabl (2018), "[m]arket power allows banks to charge depositors a spread by paying deposit rates that are low and insensitive to market rates," then granting the general public access to reserves would likely reduce banks' market power and as a result, affect the transmission mechanism of monetary policy. ${ }^{39}$ On the other hand, RFA could also lead to reduced variety in payment solutions when the greater role played by outside money leads the government to demand more standardization.

RFA might also affect the resiliency of the payment system. In the current regime consolidation and system integration (due to economies of scale) enhance the system's technological fragility (BIS, 2018). The introduction of a parallel payment system accompanying RFA could counteract that trend and offer significant gains from diversification. It goes without saying that the abolition of cash would be counter productive from a resilience point of view.

Still other arguments relate to financial inclusion or government oversight over the payment system (see, for example, BIS, 2018).

Last but not least, the introduction of RFA would end what appears to be a slightly absurd situation in countries that prohibit citizens from using cash - the only legal tender accessible to the general public - for larger transactions, thereby essentially forcing them to use privately issued money instead. Opening the central bank's balance sheet to the public would constitute a more liberal approach than restricting access to financial institutions.

\section{Conclusion}

The proposal to issue digital central bank money for use by the general public enjoys surprisingly strong support among finance practitioners but equally often faces skepticism, in particular by central bank representatives. ${ }^{40}$ A typical line of argument put forward

\footnotetext{
${ }^{39}$ According to BIS (2018), interest paying RFA would have an impact on the transmission of policy rates.

${ }^{40}$ For a recent cautionary view, see Fatás and Weder di Mauro (2018). For a more optimistic assessment, see Dyson and Meaning (2018).
} 
by the skeptics emphasizes that the traditional approach has served the public and the financial system well, and that RFA could have disruptive effects. This argument is not convincing: The "traditional approach" has evolved over the years and will continue to evolve; and in the absence of a clear counterfactual, it is difficult to assess whether it really has worked "well."

I have argued in this paper that from a macroeconomic point of view, RFA need not have disruptive effects and if it does have such effects, they might well occur in other areas or have different signs than what is typically suggested. For example, RFA could increase the incentive to extend credit but might undermine the political support for implicit financial assistance to banks. This suggests that the discussion about digital central bank money could benefit from well articulated, coherent, formal models that clarify equivalence relations as well as sources of non-equivalence. This paper is a step in that direction. In work in progress (Brunnermeier and Niepelt, 2018) we formalize some of the arguments from sections 4 and 5 .

\section{References}

Andalfatto, D. (2015), Fedcoin: On the desirability of a government cryptocurrency. Blogpost, MacroMania, February 3.

Auerbach, A. J., Gokhale, J. and Kotlikoff, L. J. (1994), 'Generational accounting: A meaningful way to evaluate fiscal policy', Journal of Economic Perspectives 8(1), 7394.

Barrdear, J. and Kumhof, M. (2016), The macroeconomics of central bank issued digital currencies, Staff Working Paper 605, Bank of England, London.

Barro, R. J. (1974), 'Are government bonds net wealth?', Journal of Political Economy 82(6), 1095-1117.

Barro, R. J. (1979), 'On the determination of the public debt', Journal of Political Economy 87(5), 940-971.

Bech, M. and Garratt, R. (2017), 'Central bank cryptocurrencies', BIS Quarterly Review 1709, 55-70.

Benes, J. and Kumhof, M. (2012), The Chicago plan revisited, Working Paper 12/202, International Monetary Fund, Washington.

Berentsen, A. and Schär, F. (2018), 'The case for central bank electronic money and the non-case for central bank cryptocurrencies', Federal Reserve Bank of St. Louis Review 100(2), 97-106.

BIS (2018), Central bank digital currencies, Report, BIS: Committee on Payments and Market Infrastructures, and Markets Committee, Basel. 
Bordo, M. D. and Levin, A. T. (2017), Central bank digital currency and the future of monetary policy, Working Paper 23711, NBER, Cambridge, Massachusetts.

Brunnermeier, M. K. and Niepelt, D. (2018), On the equivalence of private and public money. Mimeo.

Buiter, W. H. (2009a), Negative interest rates: When are they coming to a central bank near you? Blogpost, FT Maverecon, May 7.

Buiter, W. H. (2009b), Negative nominal interest rates: Three ways to overcome the zero lower bound, Working Paper 15118, NBER, Cambridge, Massachusetts.

Cecchetti, S. G. and Schoenholtz, K. L. (2018), Universal central bank digital currency? Blogpost, Money \& Banking, April 22.

Chamley, C. and Polemarchakis, H. (1984), 'Assets, general equilibrium and the neutrality of money', Review of Economic Studies 51(1), 129-138.

Chapman, J., Garratt, R., Hendry, S., McCormack, A. and McMahon, W. (2017), Project Jasper: Are distributed wholesale payment systems feasible yet?, in B. of Canada, ed., 'Financial System Review', Bank of Canada, Ottawa, chapter 1, pp. 1-11.

Diamond, D. W. and Dybvig, P. H. (1983), 'Bank runs, deposit insurance, and liquidity', Journal of Political Economy 91(3), 401-419.

Diamond, P. A. (1965), 'National debt in a neoclassical growth model', American Economic Review 55(5), 1126-1150.

Drechsler, I., Savov, A. and Schnabl, P. (2018), Banking on deposits: Maturity transformation without interest rate risk, Working Paper 24582, NBER, Cambridge, Massachusetts.

Dyson, B. and Meaning, J. (2018), Would a central bank digital currency disrupt monetary policy? Blogpost, Bank Underground, May 30.

European Commission (2016), Fiscal sustainability report, Institutional Paper 18, European Union, Luxembourg.

Fatás, A. and Weder di Mauro, B. (2018), Cryptocurrencies challenge to central banks. Blogpost, VoxEU, May 14.

Fisher, I. (1935), 100\% Money, Aldephi, New York.

Fisher, I. (1936), '100\% money and the public debt', Economic Forum (April-June), 406420.

Friedman, M. (1969), The optimum quantity of money, in M. Friedman, ed., 'The Optimum Quantity of Money and Other Essays', Aldine, Chicago, chapter 1, pp. 1-50. 
Gonzalez-Eiras, M. and Niepelt, D. (2015), 'Politico-economic equivalence', Review of Economic Dynamics 18(4), 843-862.

Goodfriend, M. (2000), 'Overcoming the zero bound on interest rate policy', Journal of Money, Credit, and Banking 32(4), 1007-1035.

Groff, J.-F. (2013), The case for digital legal tender. Blogpost, FT Alphaville, April 16.

Hayek, F. A. (1945), 'The use of knowledge in society', American Economic Review 35(4), 519-530.

Kahn, C. M., McAndrews, J. and Roberds, W. (2005), 'Money is privacy', International Economic Review 46(2), 377-399.

Kaier, K. and Müller, C. (2015), 'New figures on unfunded public pension entitlements across Europe: Concept, results and applications', Empirica 42, 865-895.

Kaminska, I. (2014), The time for official e-money is NOW! Blogpost, FT Alphaville, January 22.

Kaminska, I. (2017), Central bank digital currencies: The asset side limitation. Blogpost, FT Alphaville, July 3.

Kay, J. (2009), Narrow Banking: The Reform of Banking Regulation, Centre for the Study of Financial Innovation, London.

Kimball, M. (2013), How and why to eliminate the zero lower bound: A readers guide. Blogpost, Confessions of a Supply-Side Liberal, March 25.

King, M. (2016), The End of Alchemy: Money, Banking, and the Future of the Global Economy, Norton, New York.

Kocherlakota, N. R. (1998), 'Money is memory', Journal of Economic Theory 81(2), 232251.

Koning, J. P. (2014), Fedcoin. Blogpost, Moneyness, October 19.

Koning, J. P. (2018), Critiquing the Carney critique of central bank digital currency. Blogpost, Moneyness, April 15.

Kotlikoff, L. J. (2010), Jimmy Stewart is Dead: Ending the Worlds Ongoing Financial Plague with Limited Purpose Banking, John Wiley \& Sons, New Jersey.

Kotlikoff, L. J. and Goodman, J. C. (2009), Back to basics. Online article, New Republic, May 14.

Kydland, F. E. and Prescott, E. C. (1982), 'Time to build and aggregate fluctuations', Econometrica 50(6), 1345-1370. 
Lucas, R. E. (1976), 'Econometric policy evaluation: A critique', Carnegie-Rochester Conference Series on Public Policy pp. 19-46.

McAndrews, J. (2017), The case for cash, Working Paper 679, Asian Development Bank Institute, Tokyo.

McMillan, J. (2014), The End of Banking: Money, Credit, and the Digital Revolution, Zero/One Economics, Zurich.

Melaschenko, P. and Reynolds, N. (2013), 'A template for recapitalising too-big-to-fail banks', BIS Quarterly Review pp. 25-39.

Modigliani, F. and Miller, M. H. (1958), 'The cost of capital, corporation finance and the theory of investment', American Economic Review 48(3), 261-297.

Monetary Authority of Singapore (2017), Project Ubin: SGD on distributed ledger, White paper, Monetary Authority of Singapore, Singapore.

Motamedi, S. (2014), Will Bitcoins ever become money? A path to decentralized central banking. Blogpost, Tannu Tuva Initiative, July 21.

Niepelt, D. (2004), 'Tax smoothing versus tax shifting', Review of Economic Dynamics $7(1), 27-51$.

Niepelt, D. (2014a), Narrow banking proposals. Blogpost, Panta Rhei, December 4.

Niepelt, D. (2014b), Reserves for everyone - towards a new monetary regime? Blogpost, Panta Rhei, December 4.

Niepelt, D. (2015), Reserves for everyone - towards a new monetary regime? Blogpost, VoxEU, January 21.

Payments Canada, Bank of Canada and R3 (2017), Project Jasper: A Canadian experiment with distributed ledger technology for domestic interbank payments settlement, White paper, Payments Canada, Ottawa.

Persson, T. and Tabellini, G. (2000), Political Economics, MIT Press, Cambridge, Massachusetts.

Ramsey, F. P. (1927), 'A contribution to the theory of taxation', Economic Journal $37(145), 47-61$.

Raskin, M. and Yermack, D. (2016), Digital currencies, decentralized ledgers, and the future of central banking, Working Paper 22238, NBER, Cambridge, Massachusetts.

Reiser, N. and Wyss, L. (2018), 'Vollgeld-Initiative und Alternativkonzepte', Schweizerische Zeitschrift für Wirtschafts- und Finanzmarktrecht 90(2), 164-178.

Rogoff, K. S. (2016), The Curse of Cash, Princeton University Press, Princeton. 
Sargent, T. J. (1987), Dynamic Macroeconomic Theory, Harvard University Press, Cambridge, Massachusetts.

Sveriges Riksbank (2017), The Riksbank's e-krona project, Report 1, Sveriges Riksbank, Stockholm.

Tirole, J. (2006), The Theory of Corporate Finance, Princeton University Press, Princeton.

Tobin, J. (1985), 'Financial innovation and deregulation in perspective', Bank of Japan Monetary and Economic Studies 3(2), 19-29.

Tobin, J. (1987), The case for preserving regulatory distinctions, in 'Restructuring the Financial System, Proceedings of the Economic Policy Symposium, Jackson Hole', Federal Reserve Bank of Kansas City, Kansas City, chapter 9, pp. 167-183.

Tolle, M. (2016), Central bank digital currency: The end of monetary policy as we know it? Blogpost, Bank Underground, July 25.

UBS (2016), Utility Settlement Coin concept on blockchain gathers pace. News Release, August 24.

Wallace, N. (1981), 'A Modigliani-Miller theorem for open-market operations', American Economic Review 71(3), 267-274. 